ISSN 1392-3196 / e-ISSN 2335-8947

Zemdirbyste-Agriculture, vol. 104, No. 4 (2017), p. 377-382

DOI 10.13080/z-a.2017.104.048

\title{
Application of statistics in plant and crop research: important issues
}

\author{
Steponas RAUDONIUS \\ Aleksandras Stulginskis University \\ Studentų 11, Akademija, Kaunas distr., Lithuania \\ E-mail: steponas.raudonius@asu.lt
}

\begin{abstract}
Proper application of experimental statistics is very important issue in plant and crop research. Results of the surveys of research papers published in agricultural and biological journals show that very often statistics is used or interpreted incorrectly by authors. Researchers usually do not pay enough attention to correct statistics application in all stages of the investigation. The aim of this paper is to stress the main points on widely used statistical methods in plant and crop research. The paper includes topics on research design and statistical analyses, basic assumptions and transformations, ANOVA application, regression and correlation analyses, presentation of research results. Suggestions on proper usage of statistical methods in all stages of crop research are provided. This paper does not cover statistical methods which are beyond traditional ANOVA and regression and more advanced computer packages are needed to perform them.
\end{abstract}

Key words: analyses, ANOVA, design, experiment, regression, replication.

\section{Introduction}

Application of statistical methods assists researchers in all stages of investigation: from planning to writing a publication. But we should keep in mind that statistics cannot help if the investigation is poorly designed. On the other hand, inappropriate application of statistical methods leads to the incorrect conclusions. The quality of the investigation results and conclusions very much depends on that how experiment design and statistical analyses of its results correspond to each other (Rudolph et al., 2016). Better quality of investigation planning, conducting and reporting is usually achieved at the research centres where scientists and professional statisticians work together (Fenkon, 1995). But in most cases researchers use statistical methods according to their knowledge and understanding. Surveys of biological and agricultural journals indicate that at the end of last century statistics was used or interpreted incorrectly by authors in up to $70 \%$ of research papers (Johnson, Berger, 1982). We should expect that nowadays the situation is better. I checked my remarks on research manuscripts for some agricultural journals in the period of 20132017 and found out that $55 \%$ of the manuscripts should be improved according to the usage and interpreting of statistical analyses results. Similar results are presented by Kramer et al. (2016). They examined publications in some volumes of the Journal of the American Society for Horticultural Science (JASHS). Almost half of the examined articles had problems with experimental statistics application. Mistakes in planning of experiments and application of statistical methods occur in papers from other research fields as well. For example, results of survey of papers published in the United Kingdom and the United States reporting research data on animals, show that only $59 \%$ of the studies stated the hypotheses or objective, $87 \%$ did not use randomization; only $70 \%$ of publications had information on measures of error or variability (Kilkenny et al., 2009).

Usually some mistakes occur already at planning stage of investigation. Very often application of statistical methods does not correspond to the experimental design. In some cases, authors pay too much attention to application of statistical methods forgetting explanation the biological meaning of the research results. Very often insufficient information is provided on how the statistical analyses were performed. The aim of this paper is to stress the main points on widely used statistical methods in plant and crop research and make suggestions on proper usage of statistical methods in all stages of the investigation.

\section{Research design and statistical analyses}

It is very important to develop a proper design for all kinds of investigation: field, glasshouse, laboratory experiments and observational studies. At the beginning, experimental unit should be clearly defined. The 
experimental unit is the smallest unit to which treatment is applied (Federer, Crossa, 2005). For example, plot of field experiment, pot of glasshouse experiment, Petri dish of laboratory experiment or individual plant to be sampled for genetic investigation. Usually experimental unit is larger than observational or measurement unit. Chosen experimental unit should enable proper treatment application and treatments should enable the hypotheses tested.

Usually treatments are replicated in space and time. It is very important to distinguish true replicate and pseudoreplicate. True replicate takes place when treatment is applied to several independent experimental units. When several measurements (sub-sampling) are taken from the same sample we do not have a situation of true replication. For example: measuring separately plants from one pot, treated with herbicide; composing one soil sample from a field experiment plot and repeating four times the same chemical analysis. In such case treatment was applied only to one experimental unit and here are no true replicates. Researcher should not be mistaken planning true replicates for laboratory experiments as well (Morrison, Morris, 2000; Onofri et al., 2010). In some cases investigation can be done without true replicates, but then traditional statistical methods ANOVA or regression and correlation cannot be applied. Then other appropriate statistical methods should be used for data evaluation such as confidence interval (CI) test, $t$ test, indicators of basic statistics: standard deviation (SD), standard error (SE) and coefficient of variation (CV).

Precision of research results and quality of conclusions very much depend on the number of replicates. A significant relationship is established between the number of replicates and the standard error (Fig.).

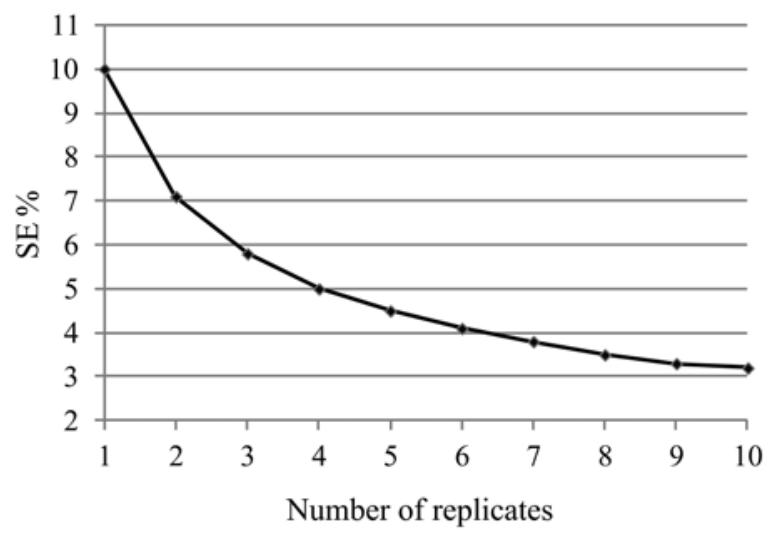

Figure. Dependence of the standard error (SE) on the number of replicates $\left(R^{2}=0.79, P \leq 0.01\right)$, according to Remer and Dospechov (Dospechov, 1985)

For agronomic experiments, 4-6 replicates are usually an optimum number, but in some cases it is necessary to apply up to 8 replicates. For example, when an experiment is conducted on small plots, has very few treatments, small differences between treatments are expected. Application of experimental statistics can help to choose proper number of replicates. Equation 1 can be used to calculate proper number of replicates:

$$
n=\frac{2 t^{2} S^{2}}{d^{2}}
$$

where $t$ is value from $t$ table according to probability level and error (residual) degrees of freedom, $S^{2}$ - variance (actual value from data of similar experiments) and $d$-expected difference between two treatments.

Because the significance of the difference between two treatments can be tested by $t$-test:

$$
t=\frac{d}{\mathrm{SED}}=\frac{d}{\sqrt{2 \mathrm{SE}^{2}}}=\frac{d}{\sqrt{2 S^{2} / n}},
$$

where $t$ is calculated $t$ value, SED - standard error of difference and SE - standard error.

Calculation of required number of replicates also can be based on the least significant difference (LSD):

$\mathrm{LSD}=t \times \mathrm{SED}=t \times \sqrt{2} \mathrm{SE}^{2}=t \times \sqrt{2} S^{2} / \mathrm{n} \quad$ (3)

Expected significant difference between two treatments should not be less than LSD at a specified significance level:

$$
t \times \sqrt{2} S^{2} / n \leq d
$$

To use methods of experimental statistics correctly it is necessary to apply randomization in the design of all kinds of experiments. Randomization is an objective method of random allocation of treatments or experimental material on the experimental units to get independent errors.

Another important aspect in research planning is application of proper sampling, especially choosing correct sampling size in each experiment unit. Mean of sampling data should correspond to population mean at wanted precision level. For that we also can use statistics. We can get initial data in several ways: 1) data of previous similar experiments conducted at similar conditions, 2) data of ongoing similar experiments conducted at similar conditions, and 3) specially planned sampling for determining of sampling size. Before determining sampling size of a certain variable it is worth analysing data of similar experiments in similar conditions. We should find out what size of difference between treatments was significant and what sampling size was used. If we plan to get similar differences, we can use the same sampling size. But if we expect smaller differences, we have to increase sampling size.

Planned sampling size can be corrected in the ongoing experiment. At the beginning we do sampling on experimental units only of two treatments, between which we expect significant difference. We instantly do statistical analyses for that initial data applying $t$ or $C I$ test. If we manage to prove significant difference between chosen two treatments using planned sampling size we can prolong sampling on all units of the experiment. If we fail to reject null hypotheses, we have to increase sampling size.

Sometimes variability level of the investigated indicator is not known. In such case it is worth doing preliminary sampling and calculating statistical indicators (e.g., CV, SD or SE) for different sampling size.

\section{Basic assumptions and transformations}

Reliable conclusions could be made only from results which satisfy basic assumptions when traditional statistics is applied. At least three key assumptions should be satisfied: normality, homogeneity of variance and independence of experimental errors.

Assumption of normality states that errors are normally distributed. It means that deviations also arise from a normal distribution. Chart of deviations or residuals of experimental data can be helpful in evaluating 
distribution character of errors. Before application of statistical methods a researcher should check out how big data differences are between blocks of replications. When there are substantial differences normality assumption may be not satisfied (Hoshmand, 2006). The data of pests per plant or leaf, weed density data, data of counts or percentage scores are usually not normally distributed.

Normality assumption can be realized in such ways: 1) increasing sampling size within experimental units, and 2) applying data transformation.

Assumption of homogeneity means that variance of treatments should be similar. In many cases differences between averages of treatments are not big, this assumption is satisfied and ANOVA or regression analyses are correct. When big differences between treatment averages occur, variance of treatments is usually very different and homogeneity assumption is violated. This situation usually happens when researcher includes untreated control in the experiment. Assumption of homogeneity can be satisfied by: 1) grouping treatments into homogeneous groups according to variability, 2) excluding data from ANOVA procedure of treatment whose average markedly differs from others (such average differs significantly from other treatments averages without formal statistical analyses), and 3) applying data transformation.

Assumption of independent errors means that the error of one observation is not correlated with that of another. For example, if researcher applies the same treatment to experimental units which are located very close, their results will be more similar than those when units are located at bigger distance. The lack of independence may arise when observations are grouped, for example in the cases of pseudoreplications, repeated measures, subsampling (Onofri et al., 2010). Assumption of independent errors can be satisfied applying proper randomization, using data only of true replicates (averages of subsampling data) and applying split-plot design for repeated measures or subsampled data. Data of repeated measurements over time or subsampling data could be taken as subplot data for statistical evaluation (Onofri et al., 2010). For example, if we investigated action of three growth regulators using five replicates and measured height of winter wheat stems four times per season split-plot design for statistical analyses can be applied in such a way: main plots $=$ application of growth regulators, measurement time $=$ sub-plots. To meet assumptions, proper actions should be taken during planning and conducting of experiments. Data transformation should be taken if large deviations from normality and homogeneity occur. Usually logarithmic, square root and arc sine transformations are applied.

Logarithmic transformation is suggested if there is evidence for relationship between means and standard deviations and assumption of homogeneity is violated or data show skewed distribution. The original data are converted to $\log _{10} x$ before statistical analyses. We should keep in mind that this way of transformation is not suitable for negative and zero values. In such case $\log (x+c)$ should be applied, where $\mathrm{c}$ is constant and equals 0.5 or 1 . If there are big set of zero values among data, another way of transformation should be applied (Hoshmand, 2006).

Square root transformation, $x^{\prime}=\sqrt{ } x$, is applied for non-negative values. This type of transformation is suitable when the means and the variances are proportional for each treatment or data skewness is obvious. If many values are small, especially some zero values exist, it is better to use transformation $x^{\prime}=\sqrt{x}+0.5$ or $x^{\prime}=\sqrt{x}+1$. However, the square root transformation is not as effective as $\log$ transformation. In some cases, log transformation over-corrects skewness or variance heterogeneity and then square root transformation is applicable.

Arc sine transformation, $x^{\prime}=\arcsin \sqrt{ } x$, is most appropriate when data belong to percentages or proportions and normality assumption is violated. Usually this transformation is recommended when the range of percentages is more than 40 . If data values are between 30 and 70, transformation is not recommended. Sometimes variation of values close to $0 \%$ and $100 \%$ is much lower than that of values around 50 percent. In such case, arc sine transformation is appropriate too. When regression models are applied, it is necessary to transform both sides (response and predictor) of model. Researcher should be confident that data transformation is really needed and actually effective to meet basic assumptions (Onofri et al., 2010). More suggestions on data transformation can be found in Hoshmand (2006), Palaniswamy and Palaniswamy (2006) and Welham et al. (2015).

\section{ANOVA application}

ANOVA is widely used to statically evaluate experimental data. This method is especially applicable for data of experiments with qualitative explanatory variables (treatments). Researcher should choose ANOVA model very responsibly to get reliable conclusions of the investigation. Model selection depends on the type of the experiment and goal or hypotheses of the research.

Single-factor experiments. Completely randomized design (CRD) and randomized complete block design (RCBD) are more often used for singlefactor experiments. Researcher should keep in mind how experiment is planned and what model to use (Table 1), because sources of variation are not the same. In the case of CRD variance of replication is absent. Latin square design and incomplete block design are rarely used by plant researches. If we apply such design, we should use adequate model ANOVA.

Table 1. Comparison of single-factor analyses of variance in CRD and RCBD

\begin{tabular}{|c|c|c|c|c|c|c|c|}
\hline \multirow{2}{*}{$\begin{array}{l}\text { Source of } \\
\text { variance }\end{array}$} & \multicolumn{2}{|c|}{$\begin{array}{l}\text { Degree of freedom } \\
\text { (DF) }\end{array}$} & \multicolumn{2}{|c|}{$\begin{array}{l}\text { Sum of square } \\
\text { (SS) }\end{array}$} & \multicolumn{2}{|c|}{$\begin{array}{l}\text { Mean square } \\
\text { (MS) }\end{array}$} & \multirow{2}{*}{$\begin{array}{c}\text { Variation ratio } \\
(F)\end{array}$} \\
\hline & CRD & RCBD & CRD & RCBD & CRD & RCBD & \\
\hline Treatment & $t_{r}-1$ & $t_{r}-1$ & $\mathrm{SST}_{\mathrm{r}}$ & $\mathrm{SST}_{\mathrm{r}}$ & $\begin{array}{c}\mathrm{MST}_{\mathrm{r}}=\mathrm{SST}_{\mathrm{r}} / \\
t_{r}-1\end{array}$ & $\begin{array}{c}\mathrm{MST}_{\mathrm{r}}=\mathrm{SST}_{\mathrm{r}} \\
/ t_{r}-1\end{array}$ & $\mathrm{MST}_{\mathrm{r}} / \mathrm{MSE}$ \\
\hline Replication & - & $n-1$ & - & SSR & - & $\mathrm{MSR}=\mathrm{SSR} / n-1$ & \\
\hline Error & $t_{r} \times n-t_{r}$ & $\left(t_{r}-1\right)(n-1)$ & SSE & SSE & $\begin{array}{l}\mathrm{MSE}=\mathrm{SSE} \\
/ t_{r} \times n-t_{r}\end{array}$ & $\begin{array}{l}\mathrm{MSE}=\mathrm{SSE} / \\
\left(t_{r}-1\right)(n-1)\end{array}$ & \\
\hline Total & $t_{r} \times \mathrm{n}-1$ & $t_{r} \times n-1$ & SST & SST & & & \\
\hline
\end{tabular}


Two-factor experiments. Randomized complete block design and split-plot design are more common in two-factor experiments. Researcher should be aware that sources of variation using these two designs are different (Table 2). When split-plot design is used, data variation depends on what type of plot (main or sub-plot) treatment was applied. Two different errors (for main plots and sub-plots) should be calculated. Because of this other
ANOVA indicators and test results of split-plot will be different as compared with those when RCBD is applied. In methods section it should be indicated which factor treatments were investigated on main plots and which on sub-plots.

If we conduct three or more factor experiments it is necessary to use proper model ANOVA for data evaluation depending on experiment design as well.

Table 2. Comparison of two-factor analyses of variance in randomized complete block design (RCBD) and spit-plot design

\begin{tabular}{|c|c|c|c|c|c|c|c|c|c|}
\hline \multicolumn{2}{|c|}{ Source of variance } & \multicolumn{2}{|c|}{$\begin{array}{l}\text { Degree of freedom } \\
\text { (DF) }\end{array}$} & \multicolumn{2}{|c|}{$\begin{array}{l}\text { Sum of square } \\
\text { (SS) }\end{array}$} & \multicolumn{2}{|c|}{$\begin{array}{l}\text { Mean square } \\
\text { (MS) }\end{array}$} & \multicolumn{2}{|c|}{$\begin{array}{c}\text { Variation ratio } \\
(F) \\
\end{array}$} \\
\hline $\mathrm{RCBD}$ & Split-plot & $\mathrm{RCBD}$ & Split-plot & $\mathrm{RCBD}$ & $\begin{array}{l}\text { Split- } \\
\text { plot }\end{array}$ & $\mathrm{RCBD}$ & $\begin{array}{c}\text { Split- } \\
\text { plot }\end{array}$ & $\mathrm{RCBD}$ & Split-plot \\
\hline \multirow[t]{2}{*}{$\begin{array}{c}\text { Factor A } \\
\text { treatment }\end{array}$} & $\begin{array}{c}\text { main plot } \\
\text { treatment }(\mathrm{A})\end{array}$ & $a-1$ & $a-1$ & $\mathrm{SS}_{\mathrm{A}}$ & $\mathrm{SS}_{\mathrm{A}}$ & $\mathrm{MS}_{\mathrm{A}}$ & $\mathrm{MS}_{\mathrm{A}}$ & $\begin{array}{l}\mathrm{MS}_{\mathrm{A}} / \\
\mathrm{MSE}\end{array}$ & $\begin{array}{l}\mathrm{MS}_{\mathrm{A}} / \\
\mathrm{MSE}_{\mathrm{I}}\end{array}$ \\
\hline & error (a) & & $(n-1)(a-1)$ & & $\mathrm{SSE}_{\mathrm{I}}$ & & $\mathrm{MSE}_{\mathrm{I}}$ & & \\
\hline $\begin{array}{c}\text { Factor B } \\
\text { treatment }\end{array}$ & $\begin{array}{c}\text { subplot } \\
\text { treatment }(\mathrm{B})\end{array}$ & $b-1$ & $b-1$ & $\mathrm{SS}_{\mathrm{B}}$ & $\mathrm{SS}_{\mathrm{B}}$ & $\mathrm{MS}_{\mathrm{B}}$ & $\mathrm{MS}_{\mathrm{B}}$ & $\begin{array}{l}\mathrm{MS}_{\mathrm{B}} / \\
\mathrm{MSE} \\
\end{array}$ & $\begin{array}{l}\mathrm{MS}_{\mathrm{B}} / \\
\mathrm{MSE}_{\mathrm{II}}\end{array}$ \\
\hline \multirow[t]{2}{*}{$\begin{array}{c}\text { Interaction } \\
(\mathrm{A} \times \mathrm{B}) \\
\end{array}$} & $\begin{array}{c}\text { interaction } \\
(\mathrm{A} \times \mathrm{B})\end{array}$ & $(a-1)(b-1)$ & $(a-1)(b-1)$ & $\mathrm{SS}_{\mathrm{AB}}$ & $\mathrm{SS}_{\mathrm{AB}}$ & $\mathrm{MS}_{\mathrm{AB}}$ & $\mathrm{MS}_{\mathrm{AB}}$ & $\begin{array}{c}\mathrm{MS}_{\mathrm{AB}} / \\
\mathrm{MSE}\end{array}$ & $\begin{array}{l}\mathrm{MS}_{\mathrm{AB}} / \\
\mathrm{MSE}_{\mathrm{II}}\end{array}$ \\
\hline & error (b) & & $a(n-1)(b-1)$ & & $\mathrm{SSE}_{\mathrm{II}}$ & & $\mathrm{MSE}_{\mathrm{II}}$ & & \\
\hline Error & & $(n-1)(a b-1)$ & & SSE & & MSE & & & \\
\hline Replication & replication & $n-1$ & $n-1$ & SSR & SSR & MSR & MSR & & \\
\hline Total & total & $n a b-1$ & $n a b-1$ & SST & SST & & & & \\
\hline
\end{tabular}

Researcher should explore factors interaction results interpreting data of multifactorial experiments. If interaction is not significant, main effects should be examined. In such case, factorial experiments are equivalent to single-factor experiments. When interaction is established, researcher should examine the simple effects (e.g., $\left.a_{1} b_{0}-a_{0} b_{0}\right)$ and evaluate interaction character. In such case, main effects of the examined factors should not be presented and discussed (Hoshmand, 2006).

ANOVA tests. ANOVA results are used to test the difference between the treatment means. Two types of treatment means comparison can be used when ANOVA is applied: 1) when paired comparisons include comparison of treatment means to control (planned comparisons), 2) when paired comparisons include comparison of each possible pair of treatments (unplanned comparisons or multiple comparison procedure). What type of comparison to use depends on the objective of the investigation. Priority should be given to planned comparisons. It is suggested that researcher should think carefully if he or she really need all possible pairwise comparisons of treatment means (Petersen, 1977; Onofri et al., 2010). If we decide to apply multiple comparison procedure (MCP), we should be more careful selecting ANOVA test. Very often least significant difference (LSD) test is used by plant researchers. Gomez and Gomez (1984) recommended that LSD test should be used for all possible comparisons when the number of compared pairs is less than six. LSD value correlates with the number of treatments. Because of that, LSD test is not recommended when experiment includes big number of treatments. In such case, too many differences between treatments can be recognized as significant. This test is correct for planned comparisons when the number of treatments is not large as well (Hoshmand, 2006). LSD test allows getting more significant differences as compared with other ANOVA tests. To be more confident in formulating conclusion, it is suggested using more conservative tests. Earlier, during 1970s, Duncan's multiple range test (DMRT) was wildly used for MCP. After its criticisms, Student-Newman-Keuels test was introduced into experimental statistics. Tukey test should be a good alternative for LSD test (Chew, 1976; Madden et al., 1982; Maindonald, 1992; Onofri et al., 2010). When researcher examines quantitative variables, for example rates of fertilizers, instead of ANOVA, regression analyses should be applied to get relationship between increasing or decreasing rates of fertilizers and crop yield.

Data analyses of experiments over years. As a rule, plant experiments are conducted more than one year. It enables researcher to formulate more valid conclusions and predict what influence the investigated means will demonstrate at different meteorological conditions. Meteorological conditions cannot be predicted by researcher, so years are treated as a random variable in such experiments. Applying ANOVA for experiments over years we seek out: 1) Do investigated variables differ significantly? 2) Are results of the investigation stable at different meteorological conditions? Because of that ANOVA for experiments over years is completed in two stages: 1) ANOVA for each year data is performed, and 2) significance of treatment $\times$ year interaction is computed. If significant interaction is established, the nature of it should be examined.

Subsampling and repeated measures. In many cases, plant researcher collects data from several areas per plot, for example plant yield on randomly taken four squares of $1 \mathrm{~m}^{2}$ per each plot. Data of each square should not be treated as true replicate, because the data from the same plot are not independent. If experimenter has intention to use all data set, a split-plot ANOVA could be performed, with treatments as "main plots" and squares as "subplots". Application of split-plot ANOVA can be a solution for investigation when soil sampling is done in several depths. In this case soil depths could be treated as subplots. Plant researchers often repeat measurements 
in time to get longitudinal data of dependent variable. In this situation a simple two-factor ANOVA should not be used, because such data do not meet independence assumption. Application of split-plot ANOVA could be the solution for such data statistical analyses, with treatments as "main plots" and time as "subplots" (Onofri et al., 2010). Sequential harvests of crops are often done in the agronomic experiments. Statistical analyses of such experimental data could be performed in such ways: 1) to use all data set and apply split-plot ANOVA (treatments as "main plots" and harvest period as "subplots"), and 2) compute ANOVA for each harvest period and for summarised data of all investigation period. For the last case, data of the same replication should be summarised.

\section{Regression and correlation analyses}

When quantitative variables are investigated, it is not very important to detect significance of differences between treatment means. It is more important is to establish relationship between independent and dependent variables, for example, between increasing fertilizer rates and plant yield. Very often simple linear regression (SLR) is applied. Strait line equation expresses relationship between two variables. Graph of plotted points can demonstrate the type of regression line (Maindonald, 1992). As a result of correlation analyses nowadays coefficient of determination $\left(R^{2}\right)$ is more often used as compared with correlation coefficient $(R)$. Significance of relationship between two variables should be checked before exploring results of regression and correlation analyses. ANOVA structure of SLR is given in Table 3. In the case of experiments with replications lack-offit should be checked by using $F$-test (Tamhane, 2009; Welham et al., 2015). Applying this procedure residual variation is split to lack-of-fit and pure error variation and two $F$ tests are calculated: for regression and for lack-offit (Table 3). If $F$ test indicates lack-of-fit significance, we conclude that the SLR model is not correct for these data and we should look for the establishment of other regression models. Results of lack-of-fit test must be presented in methods section.

There are a lot of cases in plant research where linear regression cannot express true relationship between two variables. For example, the crop yield may increase to certain level when herbicide doses are increased, but yield decrease may occur because of crop damage by higher herbicide doses. If visual analyses of scatter diagram indicate curvilinear relationship, the nonlinear regression model should be applied for such data. It

Table 3. ANOVA structure comparison of usual simple linear regression (SLR) and SLR with test for lack-of-fit

\begin{tabular}{cccccccccc}
\hline \multicolumn{2}{c}{ Source of variation } & Degree of freedom (DF) & \multicolumn{2}{c}{ Sum of squares } & \multicolumn{2}{c}{ Mean squares } & \multicolumn{2}{c}{ Variation ratio $F$} \\
\hline SLR & $\begin{array}{c}\text { test for } \\
\text { lack-of-fit }\end{array}$ & SLR & $\begin{array}{c}\text { test for } \\
\text { lack-of-fit }\end{array}$ & SLR & $\begin{array}{c}\text { test for } \\
\text { lack-of-fit }\end{array}$ & SLR & $\begin{array}{c}\text { test for } \\
\text { lack-of-fit }\end{array}$ & SLR & $\begin{array}{c}\text { test for } \\
\text { lack-of-fit }\end{array}$ \\
\hline Regression & regression & 1 & 1 & SSReg & SSReg & MSReg & MSReg & $\begin{array}{c}\text { MSReg / } \\
\text { MSE }\end{array}$ & $\begin{array}{c}\text { MSReg / } \\
\text { MSPe }\end{array}$ \\
\hline Residual & residual & $N-2$ & & SSE & & MSE & & MSLof/ \\
MSPe
\end{tabular}

looks very attractive to perform polynomial models especially of high-order, because curve well follows data trends, coefficient of determination and significance of relationship is very high. Application of polynomial models always should be related to biological meaning of investigated relationship. Regression and correlation relationship may not show biological dependence of investigated variables. Researcher's responsibility is to choose proper regression model to express the relationship between examined variables. Some suggestions can be explored in selecting proper regression model: 1) priority should be given to simpler model, because this increases possibility to get similar relationship when investigation is repeated, 2) to choose model which shows relationship at higher level of significance, 3) pay attention to model with higher determination coefficient, and 4) model should be supported with biological explanation of established relationship.

\section{Presenting of research results}

Indicators of basic statistics. Basic principle for research data presentation is that every value should have indication of variability. In the cases when only basic statistics is applied, measure of variability can be standard deviation (SD), standard error (SE), coefficient of variation $(\mathrm{CV})$, standard error of difference (SED) and confidence interval (CI). These variability indicators have different meaning and should be used properly. Researcher could use SD and CV to show the variability of sampling values. SE indicates variability of the mean and possibility to get similar values by repeated sampling. SED is used together with degrees of freedom. Using $\mathrm{CV}$ test we can judge about significance of difference between two populations.

Results of multifactorial experiments and experiments over years. Information on significance of factors interaction should be presented in the case of multifactorial experiments. If researcher needs to show more results on the interaction, he/she can present ANOVA table with degrees of freedom, $F$ ratio, probability values. It is not recommended to present full ANOVA table. For example, sum of squares or mean squares values are not so important for interpretation of research results. Main effects of factors could be presented only when significant interaction is absent. If we have results of several years of the same experiment, means over years can be presented when interaction between treatments and seasons was not established.

Results of regression and correlation analyses. If regression analyse was done for data of investigation with replicates, only means of treatments should be presented. Parameters of regression equation should be indicated together with standard errors. Significance of relationship between variables usually is indicated along with equation parameters or regression line.

Presentation of transformed data. Data transformation makes some inconvenience in presenting research results because transformed values are different from the original scale. It means that statistical indicators 
of variability cannot be used along with original data. On the other hand, data on original scale should be interpreted in the research publication. The acceptable suggestion could be such: back-transform means and indicate results of significance test by letters. But in this case it is not possible to indicate variability parameters of the means. Another solution could be parallel data presentation on both scales, back-transformed data and transformed data with indication parameters of variability. The drawback of this practice is more complicated tables and more space needed.

More suggestions on data presentation can be found in publications written by Maindonald (1992), Onofri et al. (2010) and Welham et al. (2015).

\section{Final remarks}

Correct statistics application enables researcher to get reliable experimental results and produce highquality publications in crop research. For that reason, researcher should study literature on statistics application continuously, if needed, consult an expert of experimental statistics before the start of experiment, use statistics in all stages of the investigation.

Received 19092017 Accepted 13102017

\section{References}

1. Chew V. 1976. Uses and abuses of Duncan's multiple range test. Proceedings of the Florida State Horticultural Society, 89: 251-253.

2. Dospechov B. A. 1985. Methodology of field experiment ( $5^{\text {th }}$ ed.), p. 41-46 (in Russian).

3. Federer W. T., Crossa J. 2005. Designing for and analysing results from field experiments. Journal of Crop Improvement. 14 (1-2): 29-50.

https://doi.org/10.1300/J411v14n01 04

4. Fenkon J. S. 1995. How can statistician improve your interpretation? Pest Management Science, 45 (1): 77-82.

5. Gomez K. A., Gomez A. A. 1984. Statistical procedures for agricultural research $\left(2^{\text {nd }} e d.\right)$.
6. Hoshmand A. R. 2006. Design of experiments for agriculture and natural sciences, $456 \mathrm{p}$.

7. Johnson S. B., Berger R. D. 1982. On the status of statistics in phytophatology. Phytophatology, 72: 1014-1015.

8. Kilkenny C., Parsons N., Kadyszewski E., Festing M. F. W., Cuthill I. C., Fry D., Hutton J., Altman D. H. 2009. Survey of the quality of experimental design, statistical analysis and reporting of research using animals. PLoS ONE, 4(11): e7824.

https://doi.org/10.1371/journal.pone.0007824

9. Kramer M. H., Paparozzi E. T., Stroup W. W. 2016. Statistics in a Horticultural Journal: problems and solutions. HortTechnologv. 26 (5): 558-564. https://doi.org/10.21273/JASHS03747-16

10. Madden L. V., Knoke J. K., Louie R. 1982. Considerations for the use of multiple comparison procedures in phytopathological investigations. Phytopathology. 72 (8): 1015-1017. https://doi.org/10.1094/Phyto-72-1015

11. Maindonald J. H. 1992. Statistical design, analysis, and presentation issues. New Zealand Journal of Agricultural Research, 35 (2): 121-141. https://doi.org/10.1080/00288233.1992.10417710

12. Morrison D. A., Morris E. C. 2000. Pseudoreplication in experimental design for the manipulation of seed germination treatments. Austral Ecology, 25 (3): 292-296. https://doi.org/10.1046/j.1442-9993.2000.01025.x

13. Onotri A., Carbonell E. A., Piepho H.-P., Mortimer A. M., Cousens R. D. 2010. Current statistical issues in Weed Research. Weed Research. 50 (1): 5-24. https://doi.org/10.1111/j.1365-3180.2009.00758.x

14. Palaniswamy U. R., Palaniswamy K. M. 2006. Handbook of statistics for teaching and research in plant and crop science, $652 \mathrm{p}$.

15. Petersen R. G. 1977. Use and misuse of multiple comparison procedures. Agronomy Journal, 69 (2): 205-208. https://doi.org/10.2134/agronj1977.00021962006900020003x

16. Rudolph S., Wongleecharoen C., Lark R. M., Marchant B. P., Garré S., Herbst M., Vereecken H., Weihermüller L. 2016. Soil apparent measurements for planning and analyses of agricultural experiments: a case study from WesternThailand. Geoderma, 267: 220-229.

17. Tamhane A. C. 2009. Statistical analyses of designed experiments: theory and applications, p. 41-50.

18. Welham S. J., Gezan S. A., Clark S. J., Mead A. 2015. Statistical methods in biology: design and analysis of experiments and regression, $608 \mathrm{p}$.

\title{
Statistikos taikymas augalų ir pasėlių tyrimuose: svarbiausi aspektai
}

\author{
S. Raudonius \\ Aleksandro Stulginskio universitetas
}

\begin{abstract}
Santrauka
Siekiant sèkmingai atlikti augalų ir pasėlių tyrimus, labai svarbi prielaida yra tinkamas eksperimentinės statistikos taikymas. Šios srities tyrèjai skiria nepakankamai demesio tinkamam statistikos taikymui visais tyrimo etapais. Straipsnio tikslas - atkreipti dèmesị ị svarbiausius plačiai taikomų statistinių metodų momentus atliekant augalų ir pasèlių tyrimus. Jame aptariama tyrimo planavimo ir statistinès analizès vienové, pagrindinių statistinès analizès prielaidų ir duomenų transformavimas, dispersinè analizè, regresinè ir koreliacinè analizès, tyrimo rezultatu pateikimas. Pateikiama patarimų, kaip tinkamai taikyti statistinius metodus visais augalų ir pasèlių tyrimo etapais. Straipsnyje neanalizuojami metodai, kurių neapima tradicinè dispersinè bei regresinè analizè ir kuriems taikyti reikia sudètingesnių kompiuterinių programų.
\end{abstract}

